GRASAS Y ACEITES 71 (1)

January-March 2020, e340

ISSN-L: 0017-3495

https://doi.org/10.3989/gya.1061182

\title{
Effects of smoking processes on the nutritional value and fatty acid composition of Zander fish (Sander lucioperca)
}

\author{
N. Bouriga ${ }^{\mathrm{a}, \mathrm{b}, \bigotimes}$, S. Bejaoui ${ }^{\mathrm{a}}$, B. Jemmalic ${ }^{\mathrm{c}}$ J.P. Quignard ${ }^{\mathrm{d}}$ and M. Trabelsi $^{\mathrm{a}}$ \\ ${ }^{a}$ Ecology, Biology and Physiology Laboratory of Aquatic organisms, Biology department, \\ Faculty of Science of Tunis, University of Tunis El Manar, 2092, Tunis, Tunisia. \\ ${ }^{\mathrm{b}}$ High institut of Aquaculture and fishing of Bizerte, BP15, 7080 Menzel Jemil, Tunisie. \\ ${ }^{\mathrm{c}}$ ADIPARA Lab, School of Agriculture of Mateur, University of Carthage, Carthage, Tunisia \\ ${ }^{\mathrm{d}}$ Laboratoire d'Ichtyologie, Université de Montpellier II, Sciences et Techniques Languedoc, \\ Place Eugène Bataillon, Case 102, 34095, Montpellier Cedex 5, France.
}

Corresponding author: hanounawsset@live.fr

Submitted: 27 October 2018; Accepted: 25 February 2019; Published online: 13 January 2020

2020SUMMARY: This study aimed to estimate the nutritional quality of Sander lucioperca fillets and alterations in lipid quality following hot and cold smoking processes. Our results revealed that the total fat content of zander fil-lets was $1.86 \mathrm{~g} / 100 \mathrm{~g}$. Polyunsaturated fatty acids (PUFAs) were higher than saturated and monounsaturated fatty acids in fresh tissue samples. Arachidonic, docosahexaenoic and eicosapentaenoic acids were the most abundant PUFAs. Differences in the fatty acid compositions of the smoked and fresh fillet were significant, with a decrease in (PUFAs) in the proportion of total fatty acids. The fatty acid profile of the neutral lipids was unchanged after the cold smoking process, whereas PUFAs decreased significantly during both smoking processes, especially the hot smoking process. Our findings showed a partial alteration of polar lipids. Both smoking treatments produced lipoperoxidation and lipid oxidation in the fillets. Other investigational smoking conditions should be tested to reduce such oxidation and hydrolysis in fillets, which could be susceptible to off-flavors and off-odors.

KEYWORDS: Fatty acids; Lipoperoxidation; Smoking treatments; Zander fillets

RESUMEN: Efectos de los procesos de ahumado sobre el valor nutricional y la composición de ácidos grasos de la lucioperca (Sander lucioperca). Este estudio tuvo como objetivo estimar la calidad nutricional de los filetes de lucioperca y las alteraciones en la calidad de los lípidos tras el proceso de ahumado en caliente y en frío. Nuestros resultados revelaron que el contenido total de grasa de los filetes de lucioperca fue de 1.86 g/100 g. Los ácidos grasos poliinsaturados (PUFA) fueron más altos que los ácidos grasos saturados y monoinsaturados en muestras de tejido fresco. Los ácidos grasos araquidónico, docosahexaenoico y eicosapentaenoico fueron los PUFA más abundantes. Las diferencias en la composición de ácidos grasos del filete ahumado y fresco fueron significativas, con una disminución de la proporción (PUFA) en los ácidos grasos totales. El perfil de ácidos grasos de los lípidos neutros se mantuvo sin cambios en el proceso de ahumado en frío, mientras que los PUFA disminuyeron significativamente durante ambos procesos de ahumado, especialmente en el proceso de ahumado en caliente. Nuestros resultados mostraron una alteración parcial de los lípidos polares. Ambos tratamientos de ahumado indicaron lipo-peroxidación y oxidación de lípidos en los filetes. Otras condiciones de ahumado se deben probar en investigación para reducir dicha oxidación e hidrólisis en los filetes, que podrían ser responsa-bles de sabores y olores desagradables.

PALABRAS CLAVE: Ácidos grasos; Filetes de lucioperca; Lipoperoxidación; Tratamientos de ahumado

ORCID ID: Bouriga $\mathrm{N}$ https://orcid.org/0000-0001-6181-6896, Bejaoui $\mathrm{S}$ https:// orcid.org/0000-0002-7946-2763, Jemmali B https://orcid.org/0000-0002-3961-6350, Quignard JP https:// orcid.org/0000-0001-9722-3566, Trabelsi M https://orcid.org/0000-0001-5291-6211

Citation/Cómo citar este artículo:Bouriga N, Bejaoui S, Jemmali B, Quignard JP, Trabelsi M. 2020. Effects of smoking processes on the nutritional value and fatty acid composition of Zander fish (Sander lucioperca). Grasas Aceites 71 (1), e340. https://doi.org/10.3989/gya.1061182

Copyright: (C2020 CSIC. This is an open-access article distributed under the terms of the Creative Commons Attribution 4.0 International (CC BY 4.0) License. 


\section{INTRODUCTION}

The Sander lucioperca ( $S$. lucioperca) is an important freshwater fish species in Tunisian farming. It was introduced for the first time in Tunisia by the ONP (National Office of Fishing) in 1968 (CTA, 2009) in the dam of Nebhana using 30,000 eggs which were incubated in floating boxes. Following its introduction, the recruitment of $S$. lucioperca in dams was made naturally and the stock recovered on its own. Currently, this species is present in most Tunisian dams (CTA, 2009). The production of $S$. lucioperca in Tunisian dams had a first phase which was characterized by an exponential increase of up to 192.4 tons in 2006. By 2010, the total capture of this species was estimated at 188.7 tons, representing $16.9 \%$ of the national production of freshwater fish in Tunisia. Most $S$. lucioperca production comes from the reservoir of Sidi Salem with an average of 84.28 tons/year, followed by the dams of Sidi Barrak with an average of 36.83 tons per year (DGPA, 2010).

The Tunisian fishery market is dominated by the marine species and the demand for freshwater fish is limited, despite their high nutritional value. The price of S. lucioperca is low and not adapted to the zander fishery costs. In order to develop the prospects for these markets, the image of fresh fish must be revitalized and its high nutritional qualities must be better shown. Like marine fish, S. lucioperca is a valuable source of nutrients and moisture (Guler et al., 2007). In Tunisia, this specie is sold as a fresh product. The application of a smoking process is important to encourage the consumption of freshwater fish and to conserve the highest value of tissues with good acceptance. Smoking, such as hot, cold, liquid and electrostatic treatments, is considered the most traditional conservation method in marine products with lower value to ameliorate it taste and adopt its sensory proprieties such as taste, color... etc. (Ünlüsayin et al., 2001). In addition, this traditional procedure has become a means of producing diversified products with high added value, since it offers an additional marketing preference for some aquatic species, such as freshwater fish, which are not so appreciated by consumers. In this context, the consumption of smoked freshwater fish has increased considerably in recent years because it preserves almost all the freshness of tissues (Rorvik, 2000).

Regardless of the diverse reports on the characteristics of $S$. lucioperca flesh, no information on lipid alteration or biochemical analysis of these freshwater fish is available following the smoking process. The aim of the current study was to assess the nutritional value of $S$. lucioperca fillets and the alterations in their lipid quality following hot and cold smoking treatments.

\section{MATERIALS AND METHODS}

\subsection{Sample collection and preparation}

S. lucioperca samples were caught in February 2016 during 13 fishing operations from the dam of Sidi El Barrak (Governorate of Beja, Northwest Tunisia, $\left.37^{\circ} 01^{\prime} \mathrm{N}, 09^{\circ} 39^{\prime} \mathrm{E}\right)$. Sampling surveys were conducted during the daytime with the fishermen operating in the dams.

The fish samples were preserved in ice and transferred to the laboratory where they were weighed, measured de-headed and cleaned. The average weight and length of sampled fish were $281 \pm 20.00 \mathrm{~g}$ and $47.00 \pm 3.56 \mathrm{~cm}$, respectively. The fillets were separated into three groups: (i) the first group consisted of the raw fillets stored at $-40{ }^{\circ} \mathrm{C}$ until analysis; (ii) the second group consisted of cold smoked fillets partially dried for 2 hours in the smoking chamber (Machado 1984) with temperature fluctuating from 30 to $35^{\circ} \mathrm{C}$, and kept at $-40{ }^{\circ} \mathrm{C}$ until analysis; (iii) the third group consisted of a hot smoked treatment using an industrial smoking chamber with a peripheral smoke generator (Gonçalvez and Prentice-Hernández 1998a). This process of thermal treatment of fillets was conducted according to the following sequence: pre-drying of fish surface at $50-60{ }^{\circ} \mathrm{C}$ for $150 \mathrm{~min}$, then hot smoking at $65-70{ }^{\circ} \mathrm{C}$ for $30 \mathrm{~min}$ and finally, steaming to obtain a temperature of $68-72{ }^{\circ} \mathrm{C}$. Oak wood was used for both smoking processes. Finally, the fillets were chilled by cold air at $10{ }^{\circ} \mathrm{C}$. Smoked fish fillets were then vacuum-packed in polyethylene bags, and kept at $-40{ }^{\circ} \mathrm{C}$ until analysis for a frozen period of 3 days.

\subsection{Biochemical analysis}

\subsubsection{Moisture}

The moisture of $S$. lucioperca fillets was estimated according to the AOAC (1990) method by drying in an oven at $105^{\circ} \mathrm{C}$. The results were given as the percentage of wet weight $(n=6)$.

\subsubsection{Ash}

The Ash content of the fillets was evaluated by burning each sample for $12 \mathrm{~h}$ in an oven at $525^{\circ} \mathrm{C}$ according to the AOAC (1995) method. The results were expressed as a percentage of the wet weight (n $=6)$.

\subsubsection{Protein}

The total protein content in S. lucioperca fillets was determined according to the method of Kjeldahl (AOAC, 1990). Our results were expressed as a percentage of the wet weight $(n=3)$. Total protein content in the smoked and fresh fillets was 
determined using the method of Kjeldahl (AOAC, 1990). The results were expressed as a percentage of the wet weight $(\mathrm{n}=3)$.

\subsubsection{Lipid extraction and separation}

The lipids were determined according to the Folch et al., (1957) protocol. Ten grams of fresh or smoked fillet sample ( $\mathrm{n}=6$ for each fillet) were homogenized with a chloroform:methanol (1:2) mixture for $8-10 \mathrm{~min}$ at $4{ }^{\circ} \mathrm{C}$ using a Polytron homogenizer (Malaysia). The homogenate was added to $5 \mathrm{ml} \mathrm{NaCl}$ saturated solution and $20 \mathrm{ml}$ chloroform with Butylated hydroxytoluene (BHT;50 ppm), and then homogenized for $7 \mathrm{~min}$ and $5 \mathrm{~min}$, respectively. Then, $20 \mathrm{ml}$ of distilled water were added and homogenized again for $1 \mathrm{mn}$. The obtained mixture was incubated in and ultrasound bath for $10 \mathrm{~min}$, and vacuum cleaner with Buchner funnel and chloroform. The organic fraction was extracted with a separating funnel, dried with sodium sulphate and evaporated to dryness in the rotary evaporator (Stuart $\left.{ }^{\mathrm{TM}}, \mathrm{UK}\right)$. When evaluating, the obtained oil was solubilized in a known volume of chloroform with BHT $(50 \mathrm{ppm})$ and stored at $-20^{\circ} \mathrm{C}(\mathrm{n}=6$ for each sample). Neutral and polar lipids were isolated by liquid chromatography in a silica column (Isolute SPE column, UK) with the recovered elution of $60 \mathrm{ml}$ hexane-diethyl ether (1:2) and $20 \mathrm{ml}$ methanol, respectively.

\subsection{Fatty acid analysis}

Fatty acid methyl esters (FAMEs) were estimated according to the Lepage and Roy, (1986) protocol. The analysis was performed in a Varian Agilent $6890 \mathrm{~N}$ gas chromatograph, equipped with an autosampler and fitted with a split/splitless injector and a flame ionization detector (FID). The separation was carried out in an Innowax 30x0.25 capillary column ( $25 \mathrm{~m} \times 0.25 \mathrm{~mm}$ i.d., film thickness). The temperature was programmed from 180 to $200^{\circ} \mathrm{C}$ at $4{ }^{\circ} \mathrm{C} / \mathrm{min}$, held for $10 \mathrm{~min}$ at $200{ }^{\circ} \mathrm{C}$ and heated to $210^{\circ} \mathrm{C}$ at $4{ }^{\circ} \mathrm{C} / \mathrm{min}$, held at $210{ }^{\circ} \mathrm{C}$ for $14.5 \mathrm{~min}$ with injector and FID at $250{ }^{\circ} \mathrm{C}$. The fatty acid compositions of the polar and neutral fractions were expressed as the percentage of total fatty acids $(n=6)$. The fatty acid contents in the total lipids of the fillets were calculated by using $\mathrm{C} 21: 0$ as the internal standard $(10 \mathrm{mg} / \mathrm{ml})$ based on the peak area ratio $(\mathrm{n}=6)$.

\subsection{Peroxide value (PV)}

The peroxide value of the fillet samples was determined by the ferric thiocyanate method with slight modifications (Chapman and McKay, 1949) based on the ability of lipid peroxides to oxidize ferrous ions at a low $\mathrm{pH}$. The resulting ferric ions reacted with thiocyanate and the concentration of the complex formed was determined by spectrophotometry (Jenway 6315, UK) at $500 \mathrm{~nm}$. The standard sample was determined by the reaction of a series of aliquots of $10 \mu \mathrm{g} / \mathrm{ml}$ iron (III) chloride standard solution, $10 \mathrm{mM}$ ammonium thiocyanate, and a sufficient amount of chloroform/methanol mixture $(7: 3)$. The results were expressed in mequivalent of oxygen per $\mathrm{kg}$ of oil $\left(\right.$ meq $\left.\mathrm{O}_{2} / \mathrm{kg}\right)(\mathrm{n}=3)$.

\subsection{Thiobarbituric acid reactive substances (TBARS)}

The TBARS were assessed based on the AOAC (1998) method. An oil sample was solubilized in 1-butanol, mixed with $0.2 \%$ TBA in 1-butanol, incubated in a water bath for 2 hours at $95^{\circ} \mathrm{C}$ and then cooled under tap water. The absorbance was determined using a spectrophotometer at $532 \mathrm{~nm}$. The standard curve was established by the TBARS reaction of a series of aliquots of $0.2 \mathrm{mM}$ TMP $(1,1,3$, 3-tetramethoxypropane) prepared in 1-butanol. The results were expressed as $\mathrm{mg}$ malonedialdehyde $/ \mathrm{kg}$ of oil $(n=3)$.

\subsection{Free fatty acids}

Free fatty acids were evaluated according to the method described by Bernardez et al., (2005). $50 \mathrm{mg}$ of each sample were homogenized with cyclohexane and cupric acetate-pyridine reagent and stirred by vortex for $2 \mathrm{~min}$ and then centrifuged for $20 \mathrm{~min}$ at $9,000 \mathrm{rpm}$. The activity was detected at $710 \mathrm{~nm}$. The analysis was developed with oleic acid, which used as a standard $(\mathrm{n}=3)$.

\subsection{Statistical analysis}

All calculations were performed using SAS software (Ver. 09.00). The paired student's test was used to compare the results.

\section{RESULTS}

\subsection{Proximate chemical composition}

The changes in proximate composition of fresh and smoked S. lucioperca fillets are given in Table 1. The Total lipid and protein contents of fresh fillets amounted to 1.86 and $17.66 \%$, respectively and ash content was recorded as $1.12 \%$. Significant differences $(\mathrm{P}<0.05)$ were noted for the moisture, ash, protein, and lipid contents of S. lucioperca edible fillets after the smoking process compared to fresh fillets. Also, significant differences in the proximate composition $(\mathrm{P}<0.05)$ were found between the cold and hot processes. The results showed that lipid content increased considerably after the cold treatment $(8.98 \%)$, and especially after hot smoking (13.24\%). The moisture content in hot smoked fillets was 
significantly $(\mathrm{P}<0.05)$ lower than the cold smoked one. The percentages of crude, protein and fat in smoked fillets were significantly $(\mathrm{P}<0.05)$ higher than the fresh ones. The highest value for protein $(52.66 \pm 4.12 \%)$ and fat $(13.24 \pm 1.72 \%)$ contents were recorded for the hot smoked fish.

\subsection{Total fatty acids}

The fatty acid composition of $S$. lucioperca fillets treated by hot and cold smoking processes is presented in Table 2. PUFAs $(50.18 \%)$ represented the majority of total fatty acids in fresh fillets, followed by SFAs $(25.1 \%)$ and MUFAs $(16.9 \%)$. The amounts of n-3 and n-6 PUFA were $29.47 \%$ and $24.12 \%$, respectively, where arachidonic (AA, C20:4n-6) and docosahexaenoic acid (DHA, C22:6 n-3) were the most dominant ones.

Significant differences $(\mathrm{P}<0.05)$ were observed in the PUFA levels of fresh and smoking fillets. The level of SFAs increased with heat treatment, especially after the cold smoking treatment.

\subsection{Fatty acids of neutral and polar lipids}

The fatty acid compositions of the neutral and polar lipids of $S$. lucioperca fillets following the smoking process are given in Tables 3 and 4, respectively.

TABle 1. Chemical composition ( $\%$ on a wet weight basis) of Sander lucioperca fillets before (FZ) or after hot (HSZ) and cold (CSZ) smoking processes

\begin{tabular}{lrrrc}
\hline & \multicolumn{1}{c}{ FZ } & \multicolumn{1}{c}{ HSZ } & \multicolumn{1}{c}{ CSZ } & \multicolumn{1}{c}{ ANOVA } \\
\hline Moisture (\%) & $78.41 \pm 1.32 \mathrm{a}$ & $27.65 \pm 0.48 \mathrm{~b}$ & $32.48 \pm 0.28 \mathrm{c}$ & $* * *$ \\
Proteins (\%) & $17.36 \pm 1.13 \mathrm{a}$ & $52.66 \pm 4.12 \mathrm{~b}$ & $46.22 \pm 5.42 \mathrm{c}$ & $* * *$ \\
Lipids (\%) & $1.86 \pm 0.12 \mathrm{a}$ & $13.24 \pm 1.72 \mathrm{~b}$ & $8.98 \pm 1.81 \mathrm{~b}$ & $* * *$ \\
Ash (\%) & $1.12 \pm 0.01 \mathrm{a}$ & $4.66 \pm 0.29 \mathrm{~b}$ & $3.13 \pm 0.21 \mathrm{c}$ & $* * *$ \\
\hline
\end{tabular}

Means $(n=6)$ within rows with the same letter are not significantly different $(P<0.05)$. ANOVA: Analysis of variance (One-way ANOVA, Tukey); * Significance at $0.05 ; * *$ Significance at $0.01 ; * * *$ Significance at 0.001 .

FZ: fresh zander; HSZ: hot smoked zander; CSZ: cold moked zander.

TABLE 2. Fatty acid profile ( $\%$ total fatty acids) of total lipids in Sander lucioperca fillets before (FZ) or after hot (HSZ) and cold (CSZ) smoking processes

\begin{tabular}{lcccc}
\hline Fatty acids & FZ & HSZ & CSZ & ANOVA \\
\hline C14:0 & $3.71 \pm 0.19 \mathrm{a}$ & $6.92 \pm 0.01 \mathrm{~b}$ & $5.01 \pm 0.02 \mathrm{~b}$ & $* * *$ \\
C16:0 & $11.23 \pm 0.89 \mathrm{a}$ & $16.55 \pm 0.06 \mathrm{~b}$ & $14.41 \pm 0.07 \mathrm{c}$ & $* * *$ \\
C18:0 & $5.48 \pm 0.66 \mathrm{a}$ & $8.74 \pm 0.02 \mathrm{~b}$ & $6.31 \pm 0.02 \mathrm{~b}$ & $* * *$ \\
Other SFAs & 4.81 & 6.42 & 5.22 & - \\
Total SFAs & $25.11 \pm 0.08 \mathrm{a}$ & $38.52 \pm 0.06 \mathrm{~b}$ & $30.95 \pm 0.07 \mathrm{c}$ & $* * *$ \\
C16:1 n-7 & $3.41 \pm 1.51 \mathrm{a}$ & $2.45 \pm 0.01 \mathrm{c}$ & $3.12 \pm 0.02 \mathrm{c}$ & $* * *$ \\
C18:1 n-9 & $8.53 \pm 2.40 \mathrm{a}$ & $6.16 \pm 0.02 \mathrm{~b}$ & $7.47 \pm 0.02 \mathrm{c}$ & $* * *$ \\
C18:1 n-7 & $1.66 \pm 0.51 \mathrm{a}$ & $0.98 \pm 0.01 \mathrm{~b}$ & $1.31 \pm 0.01 \mathrm{~b}$ & $* *$ \\
Other MUFAs & 3.42 & 2.07 & 3.12 & - \\
Total MUFAs & $16.91 \pm 0.05 \mathrm{a}$ & $11.63 \pm 0.08 \mathrm{~b}$ & $15.02 \pm 0.07 \mathrm{c}$ & $* * *$ \\
C18:2 n-6 & $4.82 \pm 0.47 \mathrm{a}$ & $3.69 \pm 0.01 \mathrm{~b}$ & $4.48 \pm 0.01 \mathrm{~b}$ & $* *$ \\
C20:4 n-6 & $11.84 \pm 1.29 \mathrm{a}$ & $10.63 \pm 0.01 \mathrm{~b}$ & $11.07 \pm 0.01 \mathrm{~b}$ & $* *$ \\
C20:5 n-3 & $7.37 \pm 0.46 \mathrm{a}$ & $6.32 \pm 0.01 \mathrm{~b}$ & $6.25 \pm 0.03 \mathrm{~b}$ & $* *$ \\
C22:5 n-3 & $2.30 \pm 0.24 \mathrm{a}$ & $1.09 \pm 0.00 \mathrm{~b}$ & $2.07 \pm 0.01 \mathrm{~b}$ & $* *$ \\
C22:6 n-3 & $19.81 \pm 3.42 \mathrm{a}$ & $16.54 \pm 0.02 \mathrm{~b}$ & $17.14 \pm 0.02 \mathrm{c}$ & $* * *$ \\
Other PUFAs & 4.11 & 3.27 & 4.32 & - \\
Total PUFAs & $50.18 \pm 0.13 \mathrm{a}$ & $41.54 \pm 0.12 \mathrm{~b}$ & $45.33 \pm 0.16 \mathrm{c}$ & $* * *$ \\
\hline
\end{tabular}

Means $(n=6)$ with the same letter within rows are not significantly different $(P<0.05)$.

(One-way ANOVA, Tukey): Analysis of variance; * Significance at $0.05 ; * *$ Significance at $0.01 ; * * *$ Significance at 0.001. FZ: fresh zander; HSZ: hot smoked zander; CSZ: cold smoked zander. Other SFAs: C15:0. C17:0; Other MUFAs: C20:1n-9; Other PUFAs: C16:2n-4. C16:3n-4. C18:3n-3. C20:2n-9. C20:3n-6. C20:4n-3. 
Effects of smoking processes on the nutritional value and fatty acid composition of Zander fish (Sander lucioperca) $\bullet 5$

TABLE 3. Fatty acid compositions ( $\%$ of total fatty acids) of neutral lipids in Sander lucioperca fillets before (FZ) or after hot (HSZ) and cold (CSZ) smoking processes

\begin{tabular}{|c|c|c|c|c|}
\hline \multicolumn{5}{|c|}{ Neutral Lipids } \\
\hline & FZ & HSZ & CSZ & ANOVA \\
\hline C14:0 & $2.98 \pm 0.21 \mathrm{a}$ & $3.06 \pm 0.17 \mathrm{a}$ & $3.18 \pm 0.29 \mathrm{a}$ & NS \\
\hline C16:0 & $21.51 \pm 1.04 \mathrm{a}$ & $23.25 \pm 0.94 \mathrm{a}$ & $21.54 \pm 0.74 a$ & NS \\
\hline C18:0 & $3.24 \pm 0.17 \mathrm{a}$ & $5.63 \pm 0.23 b$ & $5.72 \pm 0.19 b$ & $* *$ \\
\hline Other SFAs & 1.63 & 1.69 & 1.48 & \\
\hline Total SFAs & $29.36 \pm 0.34 \mathrm{a}$ & $33.63 \pm 0.32 b$ & $31.92 \pm 0.61 \mathrm{a}$ & $*$ \\
\hline C16:1 n-7 & $10.99 \pm 0.32 \mathrm{a}$ & $8.78 \pm 0.19 a$ & $9.87 \pm 0.32 \mathrm{a}$ & NS \\
\hline C18:1 n-9 & $11.56 \pm 0.34 \mathrm{a}$ & $13.11 \pm 0.28 \mathrm{a}$ & $11.74 \pm 0.48 \mathrm{a}$ & NS \\
\hline C18:1 n-7 & $0.83 \pm 0.15 \mathrm{a}$ & $0.92 \pm 0.11 \mathrm{a}$ & $0.94 \pm 0.13 \mathrm{a}$ & NS \\
\hline Other MUFAs & 0.11 & 0.34 & 1.07 & \\
\hline Total MUFAs & $23.49 \pm 0.27 \mathrm{a}$ & $23.15 \pm 0.19 a$ & $23.62 \pm 0.29 a$ & NS \\
\hline C18:2 n-6 & $7.69 \pm 0.32 \mathrm{a}$ & $10.72 \pm 0.31 \mathrm{a}$ & $10.55 \pm 0.32 \mathrm{a}$ & NS \\
\hline$C 20: 4 n-6$ & $12.36 \pm 0.11 \mathrm{a}$ & $14.11 \pm 0.05 \mathrm{a}$ & $13.28 \pm 0.09 \mathrm{a}$ & NS \\
\hline$C 20: 5 n-3$ & $3.73 \pm 0.13 \mathrm{a}$ & $3.21 \pm 0.08 \mathrm{a}$ & $2.67 \pm 0.11 \mathrm{~b}$ & $* *$ \\
\hline$C 22: 5 n-3$ & $1.15 \pm 0.08 \mathrm{a}$ & $0.89 \pm 0.04 b$ & $1.17 \pm 0.16 \mathrm{a}$ & $*$ \\
\hline$C 22: 6 n-3$ & $9.73 \pm 0.17 b$ & $8.08 \pm 0.13 \mathrm{a}$ & $8.68 \pm 0.21 \mathrm{a}$ & $*$ \\
\hline Other PUFAs & 2.13 & 1.91 & 2.15 & \\
\hline Total PUFAs & $36.79 \pm 0.21 b$ & $38.92 \pm 0.17 \mathrm{a}$ & $38.45 \pm 0.24 a$ & $*$ \\
\hline
\end{tabular}

Means $(n=6)$ with the same letter within rows are not significantly different $(\mathrm{P}<0.05)$.

(One-way ANOVA, Tukey): Analysis of variance; * Significance at 0.05 ; ** Significance at 0.01 ;

*** Significance at 0.001. FZ: fresh zander; HSZ: hot smoked zander; CSZ: cold smoked zander.

Other SFAs: C15:0. C17:0; Other MUFAs: C20:1n-9; Other PUFAs: C16:2n-4. C16:3n-4. C18:3n3. C20:2n-9. C20:3n-6. C20:4n-3.

TABLE 4. Fatty acid compositions (\% of total fatty acids) of polar lipids of Sander lucioperca fillets before (FZ) or after hot (HSZ) and cold (CSZ) smoking processes

\begin{tabular}{lcccc}
\hline \multicolumn{5}{c}{ Folar Lipids } \\
\hline C14:0 & HSZ & CSZ & ANOVA \\
C16:0 & $3.04 \pm 0.11 \mathrm{a}$ & $3.28 \pm 0.08 \mathrm{a}$ & $3.22 \pm 0.13 \mathrm{a}$ & NS \\
C18:0 & $24.16 \pm 1.36 \mathrm{a}$ & $22.02 \pm 1.18 \mathrm{a}$ & $20.50 \pm 1.21 \mathrm{a}$ & $\mathrm{NS}$ \\
SFAs & $5.05 \pm 0.12 \mathrm{a}$ & $8.00 \pm 0.27 \mathrm{~b}$ & $7.23 \pm 0.25 \mathrm{a}$ & $*$ \\
C16:1 n-7 & $34.25 \pm 0.27 \mathrm{~b}$ & $33.3 \pm 0.36 \mathrm{~b}$ & $30.95 \pm 0.37 \mathrm{a}$ & $* *$ \\
C18:1 n-9 & $5.45 \pm 0.26 \mathrm{a}$ & $5.92 \pm 0.31 \mathrm{a}$ & $5.64 \pm 0.38 \mathrm{a}$ & $\mathrm{NS}$ \\
C18:1 n-7 & $19.38 \pm 0.56 \mathrm{a}$ & $19.73 \pm 1.02 \mathrm{a}$ & $18.49 \pm 0.21 \mathrm{a}$ & $\mathrm{NS}$ \\
Other MUFAs & $2.30 \pm 0.21 \mathrm{a}$ & $2.93 \pm 0.21 \mathrm{~b}$ & $2.78 \pm 0.08 \mathrm{~b}$ & $*$ \\
Total MUFAs & $27.51 \pm 0.36 \mathrm{a}$ & $28.95 \pm 0.45 \mathrm{~b}$ & $28.33 \pm 0.24 \mathrm{~b}$ & $* * *$ \\
C18:2 n-6 & $7.72 \pm 0.08 \mathrm{~b}$ & $7.67 \pm 0.07 \mathrm{c}$ & $7.66 \pm 0.09 \mathrm{c}$ & $*$ \\
C20:4 n-6 & $22.19 \pm 0.09 \mathrm{a}$ & $18.39 \pm 0.11 \mathrm{~b}$ & $16.94 \pm 0.13 \mathrm{~b}$ & $* *$ \\
C20:5 n-3 & $3.70 \pm 0.26 \mathrm{a}$ & $2.94 \pm 0.21 \mathrm{~b}$ & $3.13 \pm 0.23 \mathrm{ab}$ & $*$ \\
C22:5 n-3 & $0.97 \pm 0.12 \mathrm{a}$ & $0.66 \pm 0.06 \mathrm{~b}$ & $0.88 \pm 0.07 \mathrm{a}$ & $* *$ \\
C22:6 n-3 & $12.00 \pm 0.29 \mathrm{a}$ & $10.88 \pm 0.16 \mathrm{~b}$ & $11.11 \pm 0.28 \mathrm{c}$ & $* * *$ \\
Other PUFAs & 4.02 & 4.15 & 4.07 & \\
Total PUFAs & $40.6 \pm 0.24 \mathrm{~b}$ & $34.69 \pm 0.11 \mathrm{c}$ & $33.79 \pm 0.21 \mathrm{c}$ & $* * *$ \\
\hline
\end{tabular}

Means $(\mathrm{n}=6)$ with the same letter within rows are not significantly different $(\mathrm{P}<0.05)$.

(One-way ANOVA, Tukey): Analysis of variance; * Significance at $0.05 ; * *$ Significance at 0.01 ; *** Significance at 0.001 . FZ: fresh zander; HSZ: hot smoked zander; CSZ: cold smoked zander. Other MUFAs: C20:1n-9; Other PUFAs: C16:2n-4. C16:3n-4. C18:3n-3. C20:2n-9. C20:3n-6. C20:4n-3. 


\subsubsection{Neutral lipids}

PUFAs constitute the majority of the fatty acids of neutral lipids, followed by SFAs and MUFAs. Within each of these groups, the major fatty acids were palmitic acid (C16:0), oleic acid (C18:1n-9), and arachidonic acid (C20:4n-6), respectively. The amounts of saturated, monounsaturated and polyunsaturated fatty acid remained stable after the cold smoking process. Saturated and polyunsaturated fatty acids exhibited significant $(\mathrm{P}<0.05)$ modifications after the hot smoking process.

\subsubsection{Polar lipids}

The polar lipids showed a profile similar to neutral lipids. PUFAs were also the major group, with total amounts ranging from 33.8 to $40.6 \%$ of total fatty acids. Within this group, the main fatty acid was arachidonic acid (C20:4n-6). Based on Duncan's test, PUFAs were reduced significantly $(\mathrm{p}<0.05)$ during both smoking processes to reach 34.7 and $33.8 \%$ in hot and cold smoked samples, respectively.

\subsection{Lipid peroxidation}

Changes in the peroxide value (PV), thiobarbituric acid reactive substances (TBARS) and free fatty acids (FFAs) of $S$. lucioperca fillets following hot and cold smoking processes are given in Table 5 . The results showed that the smoking process had a significant effect $(p<0.05)$ on the development of primary oxidation products in the fillets which was indicated by a higher PV level measured in hot smoked fillets.

In fresh fillets, the TBARS value was given as $0.49 \mathrm{mg} \mathrm{MA} / \mathrm{kg}$ oil. However, a slight elevation in TBARS between smoking treatments was noted in the hot (1.31 mg MA/kg) and cold $(0.78 \mathrm{mg} \mathrm{MA} / \mathrm{kg})$ smoked fillets.

The percentage of FFAs in fresh S. lucioperc is presented as $1.25 \%$ of total lipids. FFA increased significantly $(\mathrm{P}<0.05)$ after the smoking process compared to fresh fish to reach $2.27 \%$ and $4.29 \%$ in cold and hot smoked fillets, respectively.

\section{DISCUSSION}

The total lipid and protein contents of fresh fillets were similar to those found in other species from freshwater, such as Clarias gariepinus (Kumolu-Johnson and Ndimele, 2001). Generally, the lipid content of the fillets varied among species $(1.46$ to $5.77 \mathrm{~g} / 100 \mathrm{~g})$ and was affected by the fishing season (1.20 to $18.4 \mathrm{~g} / 100 \mathrm{~g})$ (Osman et al., 2001). The ash levels of fresh fillets were similar to those found in other freshwater species such as Ctenopharyngodon idella and Cyprinus carpio (Afkhami et al., 2011). The apparent increases in lipid as well as some proximate component contents after both cold and hot smoking were mainly due to water loss by evaporation during the process. These increases were more pronounced after the hot smoking process than the cold one. In the current experiment, the difference between cold and hot smoking treatments could be attributed to the fillet composition, thickness, and weight, as well as to the smoking temperature and time. These findings are in agreement with those described by De Souza Franco et al., (2010) for Matrinxa fillets, in that the final moisture content was about $25 \%$ after hot and cold smoking processes.

The fatty acid profile reflects the highest nutritional quality of zander, which was similar to a previous study (Guler et al., 2007). Several reports have evidently shown the importance of fish lipids especially long-chain n-3 PUFAs for human health and nutrition (Sidhu, 2003). Significant differences $(p<0.05)$ were found in SFAs and PUFAs of the edible fillets after the smoking process as well as between the cold and hot processes. The apparent increases in the SFA amount, especially after hot smoking was mainly due to water loss by evaporation during this process.

The major fatty acids for the group of neutral lipids were palmitic acid (C16:0), oleic acid (C18:1n-9), and arachidonic acid (C20:4n-6). The high levels of $\mathrm{C} 18: 1$ and C16:0 were in harmony with other reports (Osman et al.,2001; Passi et al., 2002), where the major SFAs and MUFAs identified in the fish lipids typically enclosed 16 and 18 carbon atoms,

TABLE 5. Peroxide value (PV), TBARS and free fatty acids (FFA) of in total lipids of Sander lucioperca fillets before (FZ) or after hot (HSZ) and cold (CSZ) smoking processes

\begin{tabular}{lccccc}
\hline & FZ & HSZ & CSZ & ANOVA & Acceptable limit \\
\hline PV (meq active $O_{2} / \mathrm{kg}$ lipids) & $0.74 \pm 0.05 \mathrm{a}$ & $3.46 \pm 0.13 \mathrm{~b}$ & $2.63 \pm 0.13 \mathrm{c}$ & $* * *$ & $10-20 \mathrm{meq} / \mathrm{Kg}$ (Connell 1975) \\
TBARS (mg MDA/kg lipids) & $0.49 \pm 0.05 \mathrm{a}$ & $1.31 \pm 0.09 \mathrm{~b}$ & $0.78 \pm 0.08 \mathrm{c}$ & $* * *$ & $8 \mathrm{mg} \mathrm{MDA} / \mathrm{kg}$ (Ozden and Erkan, 2006) \\
FFA ( /100g lipids) & $1.25 \pm 0.16 \mathrm{a}$ & $4.29 \pm 0.12 \mathrm{~b}$ & $2.27 \pm 0.18 \mathrm{c}$ & $* * *$ & $7 \mathrm{~g} / 100 \mathrm{~g}$ (IFOMA, 1981) \\
\hline
\end{tabular}

PV: Peroxide Value. TBARS: Thiobarbituric Acid Reactive Substances. MDA: malondialdehyde. FFA: free fatty acids. Means $(\mathrm{n}=3)$ with the same letter within rows are not significantly different $(\mathrm{P}<0.05)$.

(One-way ANOVA, Tukey): Analysis of variance; * Significance at $0.05 ; * *$ Significance at $0.01 ; * * *$ Significance at 0.001 . FT: fresh zander; HSZ: hot smoked zander; CSZ: cold smoked zander. 
respectively. The noticeable reduction in PUFAs may indicate the degradation of these unsaturated fatty acids throughout smoking treatments. Such results were confirmed by the higher increases in PV and TBARS levels from the hot process than the cold one.

Polar lipids were similar to the neutral ones after both cold and hot smoking processes. In fact, PUFAs showed a significant variation after the hot smoking process. Such declines were in line with Azad shah et al., (2009), who reported significant decreases in PUFAs in herring filets during the smoking process. Because of its great amount of unsaturation, DHA declined by $26.5 \%$ after the hot smoking process. PUFAs are particularly susceptible to oxidation and degradation processes through enzymatic and chemical oxidation, which produces a large amount of volatile compounds (Kolakowska, 2002). The oxidative phenomena of membrane lipids might be one of the factors involved in the development of the distinguishing taste and flavor of the analyzed fillets during the smoking process. Triqui and Reineccius (1995) showed that lipid oxidation was associated with the decline in n-3 PUFAs, which was probably related to the change in the flavor in anchovy flesh during ripening.

The levels of peroxide value, malonedialdehyde (thiobarbituric acid reactive substances) and free fatty acids of $S$. lucioperca fillets following hot and cold smoking processes were lower than the values reported for Euthynnus lineatus (Chaijan et al., 2006). Higher PV levels were possibly due to the hot temperature of smoking and the high content of polyunsaturated fatty acids known to be very sensitive to oxidative reactions. Previous reports by Hawrysh (1990) showed that lipid oxidation occurs when oxygen molecules react with unsaturated fatty acids to produce lipoperoxides, which are influenced by various elements such as temperature, water activity, $\mathrm{pH}$, and chemical environment (Ashie et al., 1996). According to Connell (1995), the acceptable limit for human consumption of PV of oils is $20 \mathrm{meq} \mathrm{O}_{2} / \mathrm{kg}$ oil. In our present study, none the analyzed fillet oil samples reached such a value after the hot smoking process. Furthermore, hydroperoxides are decomposed into a wide range of carbonyl compounds, such as aldehydes, ketones, and other compounds which contribute to off flavors in foods as well as color and texture deteriorations (Kolakowska, 2002). Consequently, the increase in secondary oxidation products was determined through the thiobarbituric acid reactive substances.

The initial value for TBARS was $0.49 \mathrm{mg}$ MDA $/ \mathrm{kg}$ oil, signifying that lipid oxidation did not take place during the post-mortem treatment. Our experimental analysis showed that TBARS levels increased in both smoked fillets to reach a value of 1.31 and $0.78 \mathrm{mg} \mathrm{MA} / \mathrm{kg}$ oil after hot and cold smoking, respectively, which was below the permissible limit reported by (Ozden and Erkan, 2006). Goulas and Kontominas (2005) revealed that the initial TBA value of chub mackerel (Scomber japonicus) amounted to $0.23 \mathrm{mg}$ MDA/kg oil, with this value reaching 0.54 and $0.47 \mathrm{mg} \mathrm{MDA} / \mathrm{kg}$ after the application of hot and cold smoking processes. The higher TBA value noted with the smoking procedure could be attributed to the dehydration of fish fillets and to the augmented oxidation of unsaturated fatty acids as a consequence of smoking at moderately high temperatures (up to $70{ }^{\circ} \mathrm{C}$ ). Our results were in line with others given by Goktepe and Moody (1998), who detected a two-fold elevation in the TBA value of catfish fillets after smoking at a temperature up to $82^{\circ} \mathrm{C}$.

Free fatty acids (FFAs) were determined as a marker of lipolysis in the smoked fillets of S. lucioperca. The hydrolysis of acylglycerol esters (mainly triacylglycerols) is one of the imperative changes occurring in fish muscle lipids during postmortem with the discharge of FFAs. In general, the development of FFAs in fish oil during storage is known to be related to some features such as the initial lipid content, the lipolytic activity and the temperature. The percentage of FFAs in fresh S. lucioperca represented $1.25 \%$ of total lipids. Such a level was lower than those found in herring oil by Aidos et al., (2001). Usually, the FFA content in crude fish ranges from 1 to $7 \%$ (Bimbo, 1998). The FFA level increased significantly $(\mathrm{p}<0.05)$ after the smoking process compared to fresh fish to reach $2.27 \%$ and $4.29 \%$ of total fatty acids in cold and hot smoked fillets, respectively. Increases were significantly different between both treatments as well. Our obtained results indicated that both treatments were under the acceptable limit (IFOMA, 1981). Such a rise suggested that $S$. lucioperca lipid hydrolysis was produced by lipases or phospholipases, particularly in the hot smoking process. Azad Shah et al., (2009) reported that free fatty acid contents increased from 4.6 to $5.1 \%$ within 4 days of natural drying and then progressively increased up to $6.86 \%$ after 10 days.

\section{CONCLUSIONS}

The results showed that hot and cold smoking processes have significant effects on lipid quality. PV, TBARS and FFA levels increased more after the hot smoking process than the cold one, indicating a partial degradation of lipids. Our results suggest that $S$. lucioperca is a good source of lipids for the human diet. It is recommended to use the cold smoking process since it better conserves the chemical composition of tissues. Additional investigation on smoking conditions should be carried out to minimize such oxidation and hydrolysis in fillets, which could be associated to off-flavors and off-odors. 
DISCLOSURE: The authors declare no conflict of interest.

\section{REFERENCES}

Afkhami M, Mokhlesi A, Darvish Bastami K, Khoshnood R, Eshaghi N, Ehsanpour M. 2011. Survey of some Chemical Compositions and Fatty Acids in Cultured Common Carp (Cyprinus carpio) and Grass Carp (Ctenopharyngodon idella), Noshahr, Iran. Word. J. F. Mar. Sci. 3, 533-538. https://doi.org/10.13140/2.1.4317.2640

Aidos I, Van-der-Padt A, Boom RM, Luten JB. 2001. Upgrading of Maatjes herring byproducts: production of crude fish oil. J. Agric. Food Chem. 49, 3697-3704. https://doi.org/ $10.1021 /$ jf001513s

AOAC. 1990. Official methods of analysis (15th ed). Association of Official Analytical Chemists. Washington, DC.

AOAC. 1995. Official methods of analysis (15th ed). Association of Official Analytical Chemists. Washington, DC.

AOAC. 1998. Official Methods and Recommended Practices of the American Oil Chemists' Society, 5th ed. (D. Firestone, ed.). Official method Cd 19-90, 2-Thiobarbituric acid value. Champaign, Ill

Ashie INA, Smith JP, Simpson BK. 1996. Spoilage and shelf life extension of fresh fish and shellfish. C. R. FoodSci. Nut. 36, 87-121. https://doi.org/10.1080/10408399609527720

Azad shah AKM, Tokunaga C, Kurihara H, Takahashi K. 2009. Changes in lipids and their contribution to the taste of migaki-nishin (dried herring fillet) during drying. Food Chem. 115, 1011-1018. https://doi.org/10.1016/j. foodchem.2009.01.023

Bernardez M. Pastoriza L, Sampedro G, Herrera JJR, Cabo ML. 2005. Modified method for the analysis of free fatty acids in fish. J. Agric. Food. Chem. 53, 1903-1906. https:// doi.org/10.1021/jf040282c

Bimbo AP. 1998. Guidelines for characterizing food-grade fish oil. Inter. News. Fat. Oils. R. Mat. 9, 473-483.

Chaijan M, Benjakul S, Visessanguan W, Faustman C. 2006. Changes of lipids in sardine (Sardinella gibbosa) muscle during iced storage. Food. Chem. 99, 83-91. https://doi. org/10.1016/j.foodchem.2005.07.022

Chapman R, Mckay J. 1949. The Estimation of Peroxides in Fats and Oils by the Ferric Thiocyanate Method. J. Am. Oil. Chem. Soc. 26, 360-363. https://doi.org/10.1007/ BF02651444

Connell JJ. 1995. Control of fish quality. In: Fishing News Books. 4th edition, Blackwell Science, Ltd, Oxford.

CTA. 2009. Rapport d'activités techniques du Centre Technique d'Aquaculture sur la pisciculture continentale. 65P.

DE Souza-Franco MS, Viegas EMM, Kronka SN, Vidotti RM, Assano M, Gasparino E. 2010. Effects of hot and cold smoking process on organoleptic properties, yield and composition of matrinxa fillet. $R$. Brasil. Zootec. 39, 695-700. https://doi.org/10.1590/S1516-35982010000 400001

DGPA. 2010. Rapport des statistiques de pêche de la Direction Générale de la Pêche et de l'Aquaculture en Tunisie. 270P.
Folch JM, Lees GH, Sloane S. 1957. A simple method for the isolation and purification of total lipids from animal tissues. J. Biol. Chem. 226, 497-507.

Goktepe I, Moody MW. 1998. Effect of modified atmosphere packaging on the quality of smoked catfish. J. Musc. Foods 9, 375-389. https://doi.org/10.1111/j.1745-4573.1998. tb00742.x

Gonçalves AA, Prentice-Hernández C. 1998a. Fumaça líquida: uma tecnologia para de fumar pescado. Boletim SBCTA. 32 (2), 189-199.

Goulas AE, Kontominas MG. 2005. Effect of salting and smoking method on the keeping quality of chub mackerel (Scomber japonicus). Biochemical and sensory attributes. Food. Chem. 93, 511-520. https://doi.org/10.1016/j. foodchem.2004.09.040

Guler GO, Aktumsek A, Citil OB, Arslan A, Torlak E 2007. Seasonal variations on total fatty acid composition of fillets of zander (Sander lucioperca) in Beysehir Lake (Turkey). Food. Chem. 103, 1241-1246. https://doi.org/10.1016/j. foodchem.2006.10.029

Hawrysh ZJ. 1990. Stability of canola oil in Production, chemistry, nutrition and processing technology. 129 p. F. New York: Shahidi.

IFOMA. 1981. Method of analysis for chemistry value of fish oil. Hoval Lane, England: IFOMA

Kolakowska A. 2002. Lipid oxidation in food systems. In Sikorski Z. and Kolakowska A. (Eds.). Chemical and functional properties of food lipids. 133-165. London, UK: CRC Press.

Kumolu-johnson CA, Ndimele PE. 2001. Effect of salting, brining and sundrying on the shelf-life of Clarias gariepinus (LACEPEDE). Res. Rev. Sci. 2, 21-25.

Machado ZL. 1984. Tecnologia de recursos pesqueiros. Recife: Minter e Sudene. 277p.

Osman H, Suriah AR, Law EC. 2001. Fatty acid composition and cholesterol content of selected marine fish in Malaysian waters. Food. Chem. 73, 55-60. https://doi. org/10.1016/S0308-8146(00)00277-6

Özden O, Erkan N. 2006. Effect of different packing methods on the shelf life of marinated rainbow trout. Archiv für Lebensmottelhygiene 57, 69-75.

Passi S, Cataudella S, Di Marco P, De Simone F, Rastrelli L. 2002. Fatty Acid Composition and Antioxidant Levels in Muscle Tissue of Different Mediterranean Marine Species of Fish and Shellfish. J. Agric. Food. Chem. 50, 7314-7322. https://doi.org/10.1021/jf020451y

Rorvik LM. 2000. Listeria monocytogenes in the smoked salmon industry. Int. J. Food Microbiol. 2, 183-190.

Sidhu KS. 2003. Health benefits and potential risks related to consumption of fish or fish oil. Regul. Toxicol. Pharmacol. 38, 336-344. https://www.ncbi.nlm.nih.gov/ pubmed/14623484

Triqui R, Reineccius GA. 1995. Changes in flavor profiles with ripening of anchovy (Engraulis encrasicholus). J. Agric. Food. Chem. 43, 1883-1889. https://doi.org/10.1021/if00055a024

Ünlüsayin M, Kaleli S, Gülyavuz H. 2001b. The Determination of Flesh Productivity and Protein Components of Some Fish Species after Hot Smoking. J. Sci. Food Agric. 81, 661-664. https://doi.org/10.1002/jsfa.862 